\title{
Academic institutional entrepreneurs in Germany: navigating and shaping multi- level research commercialization governance
}

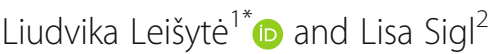

\author{
* Correspondence: liudvika.leisyte@ \\ tu-dortmund de \\ ${ }^{1}$ Center for Higher Education, \\ Faculty of Business and Economics, \\ TU Dortmund University, \\ Vogelpothsweg 78, TU Dortmund, \\ 44227 Dortmund, Germany \\ Full list of author information is \\ available at the end of the article
}

\begin{abstract}
In this article, we aim to explore the agency of scientific entrepreneurs and research managers in shaping their Triple Helix contexts. Drawing on institutional documents and in-depth interviews with research managers and scientists in the German state of North Rhine-Westphalia, the study shows that trust in scientific entrepreneurs from research managers, their scientific standing and leadership, and type of academic entrepreneurship are central in shaping the Triple Helix relationships. Research managers frame themselves as passive service-providers for scientists' commercialization activities while scientists see them as facilitating creative employment arrangements. Research managers perceive scientists as self-motivated highly creative risk-takers. The studied scientific entrepreneurs negotiate their institutional arrangements and find flexible solutions for the structural barriers within their research organisations. At the same time, they tend to avoid taking personal risks when it comes to contractual arrangements and their careers.

The study identifies two types of agency exerted to shape the Triple Helix context-bricolage and institutional entrepreneurship. Bricolage activities and the trust of research managers in the leadership and autonomy of scientific entrepreneurs prepare the basis for institutional change. This can be the ground for institutional entrepreneurship to take place and reshape the Triple Helix relationships in the particular context.
\end{abstract}

Keywords: Academic entrepreneurship, Institutional entrepreneurship, Individual agency, Research commercialization governance 
摘 要

本文旨在探索三螺旋环境形成过程中的科学创业者和研究管理人员的机构。依 据德国北莱茵威斯特伐利亚州的机构文件和对那里的研究管理人员和科学家的 深入访谈,这项研究揭示了研究管理人员对科学创业者的信任,他们的科学地位和 领导力以及AE的类型是形成三螺旋关系的核心。研究管理人员将自己定位为服 务提供者，为科学家的商业化活动提供被动的服务，而科学家则将他们看成促进创 造性的就业的安排。研究管理人员认为科学家是自我激励的具有高创造性的风 险承担者。研究型的科学创业者就其制度安排进行谈判，为其研究组织内的结构 性障碍寻找灵活的解决方案。同时，在合同安排及其职业生涯中，他们倾向于避免 承担个人风险。

这项研究确定了形成三螺旋环境的两类机构—— (资源)拼凑创业和机构创业。 拼装活动和研究管理人员对科学创业者的领导力和自主权的信任为机构变革奠 定了基础。这可以成为机构创业发生的基础,并在特定背景下重塑三螺旋关系。

\section{Résumé}

Cet article vise à explorer l'action d'entrepreneurs scientifiques et de gestionnaires de recherche dans le but de façonner leur contexte de Triple Hélice. Sur la base de documents institutionnels et d'interviews approfondis avec des gestionnaires de recherche et scientifiques dans l'Etat de la Rhénanie-du-Nord-Westphalie en Allemagne, l'étude montre que la confiance des gestionnaires de recherche dans les entrepreneurs scientifiques, leur statut et leur leadership scientifiques de même que le type d'AE jouent un rôle central dans le façonnement des relations de Triple Hélice. Les gestionnaires de recherche se définissent comme des fournisseurs passifs de services aux activités de commercialisation des scientifiques alors que ces derniers les perçoivent comme des facilitateurs d'accords créatifs d'emplois. Les gestionnaires de recherche perçoivent les scientifiques comme des preneurs de risques automotivés très créatifs. Les entrepreneurs scientifiques objet de l'étude négocient les accords institutionnels et trouvent des solutions flexibles aux barrières structurelles dans leurs organisations de recherche. Au même moment, ils ont tendance à éviter des risques personnels quand ils doivent contracter des accords ou quand il s'agit de leur carrière. Cette étude identifie deux types d'actions qui façonnent le contexte de la Triple Hélice : le bricolage ou l'entrepreneuriat institutionnel. Les activités de bricolage et la confiance des gestionnaires de recherche dans le leadership et l'autonomie des entrepreneurs scientifiques préparent la base du changement institutionnel. Cela peut servir à asseoir les bases de l'entrepreneuriat institutionnel qui réorganise les relations de la Triple Hélice dans ce contexte particulier.

\section{Resumo}

Neste artigo almejamos explorar a atuação de Empreendedores Científicos e Gerentes de Pesquisa na formação do contexto de Hélice Tríplice. Definindo em documentos institucionais e em profundas entrevistas com Gerentes de Pesquisa e Cientistas no estado alemão de North-Rhine Westphalia o estudo mostra que confiança de Gerentes de Pesquisa para com Empreendedores Científicos, sua reputação científica e liderança, bem como o tipo de Empreendedorismo Acadêmico são fundamentais na formação das relações de Hélice-Tríplice. Gerentes de Pesquisa se enquadram como provedores passivos para atividades de comercialização científica enquanto cientistas os veem como facilitadores na criação de postos de trabalhos criativos. Gerentes de Pesquisa percebem Cientistas como "assumidores de risco"

(Continued on next page) 
(Continued from previous page)

automotivados e altamente criativos. Os Empreendedores Científicos estudados negociam seus arranjos institucionais e encontram soluções flexíveis para as barreiras estruturais inerentes às organizações de pesquisa. Simultaneamente, os Empreendedores Científicos tendem a evitar assumir riscos pessoais quando se trata de arranjos contratuais e de suas carreiras.

O estudo identifica dois tipos de atuação usadas para formar o contexto de HéliceTríplice - auto-empreendedorismo e empreendedorismo institucional. Atividades autônomas e a confiança dos Gerentes de Pesquisa na liderança e autonomia dos Empreendedores Científicos preparam a base para mudança institucional. O que pode representar sustentação para empreendedorismo institucional tomar lugar e remodelar o conceito de Hélice-Tríplice em um contexto particular.

\section{Аннотация}

В настоящей статье мы поставили целью исследование работы ученыхпредпринимателей и менеджеров по перспективным разработкам в Тройной спирали. По результатам анализа ведомственных документов и глубинных интервью менеджеров и ученых Федеральной земли Германии Северный РейнВестфалия было выявлено, что в основе трехспиральных отношений лежат уверенность менеджеров в результатах работы ученых и их научных знаниях. Менеджеры по перспективным разработкам позиционируют себя как пассивных поставщиков услуг при коммерциализации научных исследований, в то время как ученые характеризуют себя как креативных инициаторов проектов. Менеджеры воспринимают ученых как целеустремленных творческих лидеров, берущих на себя риски. Опрошенные научные предприниматели анализируют существующие академические соглашения и ищут пути преодоления барьеров в исследовательских организациях. В то же время, они стремятся избежать индивидуальных рисков, когда это касается договорных обязательств и их карьеры.

В настоящей работы были выявлены два типа агентов, влияющих на структуру Тройной спирали, - творчество и институциональное предпринимательство. Творческие инициативы и вера менеджеров по перспективным разработкам в лидерство и независимость ученых-предпринимателей формирует основу институциональных изменений. Это может способствовать институциональному предпринимательству и изменению структуры Тройной спирали в определенных ситуациях.

\section{Resumen}

Usando archivos institucionales y entrevistas con investigadores y administradores en el estado alemán de Renania del Norte-Westfalia, encontramos que los administradores deciden la profundidad de su relación con los investigadores basados en el nivel de confianza que cultivan, así como el rango profesional, liderazgo, y tipo de AE que les atribuyen. El carácter de esas relaciones decide la forma que toma la Tiple Hélice.

Los administradores se consideran a sí mismos proveedores de servicios para las actividades de comercialización, mientras que los investigadores los ven como signatarios de acuerdos creativos. Los administradores perciben a los investigadores como tomadores de riesgos altamente creativos y auto motivados. Los investigadores negocian sus acuerdos institucionales y encuentran soluciones flexibles para las (Continued on next page) 
(Continued from previous page)

barreras estructurales dentro de sus organizaciones, eso sí observamos, lo hacen sin arriesgar sus fuentes de empleo propias. Este estudio identifica dos tipos de agencias: el bricolaje y el emprendimiento institucional. Las actividades de bricolaje y la confianza del administrador en el liderazgo y la autonomía de los investigadores promueven cambio institucional. Este cambio puede ser el terreno en el que emerge el emprendimiento institucional.

\section{Multilingual abstract}

Please see Additional file 1 for translation of the abstract into Arabic.

\section{Introduction}

Academic entrepreneurship (AE) ${ }^{1}$ is expected to change public research institutions ${ }^{2}$ in a fundamental way to ensure they contribute to wealth and job creation. It is widely accepted that this will be achieved by new kinds of relations between societal actors (universities, governments, industry, NGOs and new intermediary institutions), formal and informal linkages and networks (Etzkowitz and Leydesdorff 2000; Link and Siegel 2007). Empirical studies have shown that academic entrepreneurship is a quite heterogeneous phenomenon: there are strong national and regional differences in how widespread, how intense and institutionalised academic entrepreneurship is in different types of research organisations (e.g. Goel and Göktepe-Hulten 2017; Grimaldi et al. 2011). It also significantly varies in different institutional environments in terms of barriers and facilitators scientific entrepreneurs encounter (Davey et al. 2015) as well as what kind of characteristics they have (Werker et al. 2017). An "unevenness" of how scientific entrepreneurs commercialise and what their role is in commercialization in different disciplines and how research (and other) institutions accommodate $\mathrm{AE}$ is observed (Kleinman and Osley-Thomas 2014; Tuunainen and Knuuttila 2009).

One challenge in understanding these differences lies in understanding them as part of broader multi-level research and innovation governance structures and mechanisms (De Boer et al. 2007; Siegel and Wright 2015; Whitley et al. 2010) that support highly fluid Triple Helix systems (Etzkowitz and Leydesdorff 2000). Managerial organisation principles along New Public Management (NPM) -inspired reforms have been linked to the aim towards more entrepreneurial orientation in research organisations (Felt and Glanz 2004; Kezar 2014; Leišytė and Dee 2012; Etzkowitz 2013). Particularly within an institutionalist tradition, increased academic entrepreneurship is seen as the outcome of institution-building processes (e.g. Berman 2012). Without doubt, state financial support and regulation of AE have been influential across Europe and in the USA (e.g. Grimaldi et al. 2011; Sigl and Leišytè 2018). New intermediaries (technology parks, departments and agencies supporting entrepreneurship) and dynamic entrepreneurial networks have changed governance arrangements and opportunity structures for scientific entrepreneurs (Meyer and Kearnes 2013; Doganova 2013; Werker et al. 2017; Wright et al. 2008). Here, the role of technology transfer offices and their management has been underscored as they engage in intellectual property management, scout for new ideas within their research organisations and negotiate agreements between their organisations and private industry and raise awareness of the importance of patenting and licencing for their research organisations (e.g. Leišytė 2011). 
Compared to the extensive work on structural changes and linkages in the Triple Helix systems and their contribution to the knowledge economies, the agency of individual scientific entrepreneurs in commercialization of knowledge and the paths they undergo to shape their environment to their advantage is still underexplored. Studies on the individual level have often been limited to the typology of roles of scientific entrepreneurs (Etzkowitz 1997); how they respond to incentives for AE and how effective they are (Siegel et al. 2004); what they perceive as barriers to knowledge commercialization (D'Este and Patel 2007; Lockett et al. 2003); what is the likelihood of bypassing technology transfer offices (Huyghe et al. 2016); what are the determinants of academic engagement including formal commercial activities, informal commercial activities and non-commercial activities (Abreu and Grinevich 2013); the stages of academic entrepreneurial process (Tijssen 2006) or motivations to engage in AE (Balven et al. 2018; Fochler 2016; Lam 2011; Thursby and Thursby 2005; Rizzo 2015; Rosa and Dawson 2006; de Silva 2012). Particularly for the context of Germany, the role of scientists in engaging in AE has often been depicted as rather passive and inert to the top-down attempts of establishing the "third mission" (Krücken 2003; Wentland et al. 2012) or as not being aware of the technology transfer structures in their research organisations (Goel and Göktepe-Hulten 2017).

Less frequent, scientists are depicted as active protagonists of an entrepreneurial mindset (Latour 1996; Shapin 2008), as lobbyists for the case of AE (Berman 2012: 857) or as actively pursuing collaborations and multiple affiliations and industry (Hottenrott and Lawson 2017). Studying individual agency in university settings, for example, has also been rather a recent phenomenon (Hasanefendic et al. 2017; Leišyte et al. 2017). At the same time, the studies of research managers' role in $\mathrm{AE}$ on the other hand-are largely focused on the sub-organisational level, such as technology transfer offices and their impact.

In this paper, we focus on the agency of individual scientific entrepreneurs and research managers in research commercialization and institutional change in the context of multi-level governance mechanisms and linkages in the particular Triple Helix system. We understand the agency embedded in the organisational context, which is why we explore the questions both from the perspective of research managers as well as from the perspective of scientists. Our study combines these perspectives, therewith responding to the call for multi-level analyses (Siegel and Wright 2015) of AE on the one hand, while at the same time, to multiple calls for unpacking the agency of scientific entrepreneurs in knowledge commercialization (Berman 2012). The study explores the following questions:

1. What kinds of agency do research managers assume with regard to research commercialization? What kinds of agency do scientists ascribe to research managers?

2. What kinds of agency do scientists assume with regard to research commercialization? What kinds of agency do research managers ascribe to scientists?

3. How do research managers and scientists contribute to institutional change towards $\mathrm{AE}$ in their respective organisations?

To situate our study on $\mathrm{AE}$ within the particular multi-level governance context in Germany, we first explore the political and institutional contexts, provide the conceptual 
framework, describe the triangulation of methods in this study and present our data. The paper closes with the discussion and conclusion proposing future avenues for research in $\mathrm{AE}$.

\section{Research commercialization in Germany}

Germany has been described as being a "latecomer to adapting its university system to the changing knowledge economy" (Lange and Krücken 2011: 343) but is considered today to be one of the strongest performing innovation systems in the world with a strong industrial base (EC 2015; BMBF 2014: 469), having relatively favourable conditions for entrepreneurship (Davey et al. 2015). Already between 1976 and 1988, technology transfer offices (TTOs) were established in all public universities. Recently, start-up competitions organised by universities, city governments, regional economic promotion agencies provide additional resources for AE. This shift towards a knowledge economy was amongst others due to a range of federal and state policy initiatives, including a number of targeted measures to improve research commercialization conditions in research organisations. For example, EXIST, one of the most prominent programmes for promoting university-based start-ups and entrepreneurial culture at German universities, was launched in 1998 (Volkmann and Grünhagen 2014: 235-6). In its fourth stage, this programme today aims to transform selected universities into entrepreneurial universities ("Gründerhochschulen") (BMWE - Bundesministerium für Wirtschaft und Energie 2015) via the establishment of "a culture of entrepreneurship in its teaching, research and management" (Kulicke 2014: 12).

In the case of the state of North Rhine-Westphalia (NRW), governance on the state level has been particularly influential in fostering AE. NRW historically has been a heavy industry state, with mining industry at the forefront. Today, the largest industrial sectors include heavy machinery and chemical industry, followed by food industry, metal production, automotive industry, electrical engineering and electronics. In 2015, the NRW state accounted for $21.3 \%$ of the German GDP maintaining its status as the country's economically strongest region (EC-European Commission, 2018). Ranking amongst the most populous of German's 16 states (17.5 million population) with the highest density of research organisations and universities, the state supports technology transfer already since the 1960s after the radical decline of coal and steel industries. Besides the establishment of a range of universities to support local high-tech industries in NRW, it also hosts one of the oldest and largest German "technology centres" and technology parks. As a result, today NRW universities have a range of state, federal and industry support structures available to foster AE.

While in the literature the "third mission" of research commercialization is often described as strongly rejected by universities in Germany (Krücken et al. 2007: 676), recent studies have revealed that public research organisations did not necessarily oppose commercialization, but were content with their "informal transfer activities" and feared "an additional bureaucratic layer" (Lange and Krücken 2011: 364). The high level of informal AE activities in Germany (and in industrial areas like NRW in particular) makes it often difficult to determine changes in actual commercialization activities.

Another aspect of change has taken place in terms of strengthening the autonomy of universities from the state since the 1990s in NRW as one of the forerunners of these reforms in Germany (Hüther and Krücken 2018). A third important development for $\mathrm{AE}$ in Germany is a new intellectual property rights (IPR) regulation which was passed 
in 2001. The so-called professors' privilege was abolished, i.e. professors are now obliged to report any patentable inventions to allow the university to own and exploit the intellectual property while in return the university covers all costs involved in filing patents and academics are entitled to $30 \%$ of revenues from licencing. New structural arrangements such as patent exploitation agencies ("Patentverwertungsagenturen") were created to assist universities in this new task (cf. Krücken et al. 2007: 688; Kulicke et al. 2014).

The conditions for individual scientists to engage in AE still vary in NRW despite the abovementioned general shifts in Germany. This can partly be attributed to the diverse organisational landscape of research organisations. Research universities, universities of applied sciences and other public research institutions have their unique organisational structures as well as organisational cultures when it comes to AE. While technology transfer services are institutionalised within universities (TTOs), some services are outsourced to the patent exploitation agencies outside the universities. Universities of applied sciences are more centralised in their decision-making and have closer links to industry due to their applied mission compared to more research-driven research universities, where the power of professors is still holding its base alongside increased centralised management. Their decision-making lines are long and include multiple stakeholder interaction. The German science system also includes public research organisations such as for example research institutes of the Max Planck Society or Fraunhofer Society. All of them engage in knowledge commercialization, even the most basic research-oriented ones. The research institutes differ in their missions: the institutes of the Max Planck Society are rather oriented towards basic research and are largely funded by the state, the institutes of the Fraunhofer Society are oriented towards applied research and are closely linked to collaborations with the private sector. As a rule, the Societies serve as umbrella organisations for their institutes in providing TTO type of apparatuses for technology transfer, such as the Max Planck Innovation or Fraunhofer Venture (Doppelberger 2012; Mahr 2012; Lange and Krücken 2011). Research institutes are smaller organisations compared to universities and operate quite independently from their umbrella Society, thus their decision-making lines are shorter.

From the abovementioned changes, we learn that while commercialization activities used to be carried out by scientists rather informally and independently from their research organisations, the legal and structural changes of the recent two decades have brought $\mathrm{AE}$ more into the organisational bureaucracy of German research organisations. However, it is unclear how the abovementioned structural and regulatory changes have influenced $\mathrm{AE}$ practices. Evidence on this is partly inconsistent: after the first years of the EXIST programme, the creation of start-ups rather stagnated in the EXIST-programme regions, while it increased in other regions (BMBF - Bundesministerium für Bildung und Forschung, 2002). It also has been shown that the abolishment of the professors' privilege has not led to an increase of inventions at universities, only to an increase of university-assigned patents (von Proff et al. 2012). This shows that still little is known about how policies, legal frameworks and new funding programmes change AE practices in the German context, and what role scientists assume in a context in which the 
professoriate was long used to strong academic self-governance (cf. Lange and Krücken 2011: 351).

\section{Conceptual framework}

\section{Academic entrepreneurship}

There are different definitions for academic entrepreneurship and they range from those that encompass a broad range of knowledge transfer activities of scientists (e.g. Klofsten and Jones-Evans 2000) to narrower ones that only address university spin-off creation and academic start-ups (Perkmann et al. 2013; Davey et al. 2015). In this paper, we use a broad definition of academic entrepreneurship and define it as all activities and initiatives that contribute to the commercialization of knowledge and technologies that originate in research at universities and other research organisations.

Studies on AE and research commercialization have become so manifold and frequent that recent review articles (Bozeman et al. 2013; Djokovic and Souitaris 2008; Hagedoorn et al. 2000; Markman et al. 2008; Meyers and Pruthi 2011; Perkmann et al. 2013; Schmitz et al. 2017) had a challenging task to bring all the insights together. We will not attempt to repeat these efforts, but focus on those relevant for understanding the agency of scientific entrepreneurs in interaction with their institutional environment.

For understanding the institutional environment of AE, we turn to the Triple Helix model of the university-industry-government relations (Etzkowitz and Leydesdorff 2000). The model shows the importance of universities in knowledge societies. The Triple Helix model proposes that the interaction between the helixes may generate new institutional and social forms of production, transfer and application of knowledge (Etzkowitz 2008). The model suggests that within the helix, intersections between industry, university and government interact in context-specific ways in different national systems and can produce new discourses and new inter-institutional relations and hybridization (Siegel 2008). In the "balanced" Triple Helix model, hybrid (overlapping) institutions are central as they synthesise elements of university, industry and government institutional spheres in their institutional design. They are characterised by smaller scale hierarchies, permeable boundaries, few bureaucratic layers, decentralised decision-making and flexibility to respond to market demands (Ranga and Etzkowitz 2013). As underscored by Ranga and Etzkowitz (2013), boundary permeability is "an important source of organizational creativity, as individuals move among the spheres and engage in recombination of elements to create new types of organizations." (p. 31) However, it is somewhat unclear what is the role of individuals in this organisational creativity. Even though the role of spaces, institutions and linkages between the different helixes has been underscored, the role of individual agency has drawn less attention despite the acknowledgment of the importance of individuals in initiating and consolidating institutional processes (Ibid. p.12).

At the individual level, Etzkowitz (1997) identified four main styles of scientific entrepreneurs - the mogul, the sustainer, the adviser and the craftsman along the axes of compatibility with traditional academic values and the capitalization of knowledge (Etzkowitz 1997, p. 146). A recent study of the human factor in the Triple Helix context has shown that individual agency plays an important role as boundary spanner mediating between industry and university pointing to the complex processes by which different cultures of scientific and corporate entrepreneurs can be bridged (Frølund and Ziethen 2016). Literature focusing on scientists examined their motivations to transfer and commercialise knowledge 
(Lam 2011; Olmos-Peñuela et al. 2015). Further, studies have also aimed at understanding how scientific entrepreneurs maintain the balance between organisational demands for scientific and entrepreneurial activities and what this means for their identities (Leišyte and Hosch-Dayican, 2016; Ylijoki, 2003). The typology developed by Ranga and Etzkowitz (2013) of innovation organisers and entrepreneurial scientists points out the ways in which individual and institutional innovation and entrepreneurship initiate and reinforce each other. With our exploration of the agency of scientists and research managers in shaping their institutional environment (and of their research organisations specifically), we aim to contribute to this literature on the role of individuals in shaping Triple Helix relationships and fostering institutional change.

\section{Institutional entrepreneurship}

While previous research rather was interested in how organisations can modify scientists' practices (e.g. improve motivation to commercialise), our study assumes that scientists influence their organisations and are successful in leveraging institutional change to accommodate their commercialization activities. This suggests that research organisations and individuals might be mutually changing each other in the context of the Triple Helix relationships.

In exploring this, we are inspired by the concept of institutional entrepreneurship that "reintroduces agency, interests and power to institutional analysis" (cf. Garud et al. 2007: 957; Powell and DiMaggio 1991). Instead of focusing on how institutional forces create continuity in organisations, the focus of this concept is on how creative forces bring change to institutions (Garud et al. 2007), particularly in the neo-institutionalist tradition. "Institutional entrepreneurship" here is defined as "activities of actors who have an interest in particular institutional arrangements and who leverage resources to create new institutions or to transform existing ones" (Maguire et al. 2004: 657). Institutional entrepreneurs in this sense are "actors who leverage resources to create new or transform existing institutions" (Battilana et al. 2009, cf. DiMaggio 1988). Thus, it is the venture of the institutional entrepreneur to change institutions, e.g. by creating a new business model or introducing new regulations at a research organization. It is thus viewed as an "intensely political process" (Garud et al. 2007: 962).

Without digression into the structure-agency debate that often follows this thought (cf. Garud et al. 2007: 957; Powell and DiMaggio 1991), we still need to elaborate on the concept of embedded agency that we employ. We conceptualise agency as developed in context, i.e. environmental parameters can offer opportunities or set boundaries to scientists' agency but do not determine their actions. Agency, however, can be characterised differently with regard to (institutional) change. An institutional entrepreneur exerts agency by establishing new and durable institutional regulations while other forms of agency just make new practices possible for a limited amount of time without changing institutions. An example for this would be an academic who engages in "bricolage" by engaging in different "types of actions via which academics implement more or less pro-active strategies" and use and re-use a "repertoire of resources" that are available at hand to engage in change (Louvel 2013: 669). Using the available resources in new ways and combining them creatively allows academics to introduce new practices. Further, scientists may manipulate 
and symbolically comply to their environment to ensure the pursuit of research lines of their preference even given contextual constraints (Leišyte 2007, 2015; Leišyte et al. 2010) or academics can pursue initiatives to alter organisational processes (Schmidt and Lauer 2016). The latter, however, only count as institutional entrepreneurship when different organisational processes are made durable by changing institutional regulations.

The difference between these two forms of agency however is not only in the sustainability of the change they induce, it is also in the attitude towards the relation between the individual and institution they represent. While the institutional entrepreneur appropriates the institutional structure and makes it fit to his/her ventures, engaging in "bricolage" has a rather instrumental relation to the institution, claiming and combining creatively existing resources, but not (necessarily) claiming institutional change. An investigation into scientists' agency in their organisational contexts thus tells us not only about if and how different commercialization activities get embedded in academic institutions, but also about how institutions may change in the process.

\section{Methodology and empirical material}

This paper builds on semi-structured qualitative interviews $\left(1-1 \frac{1}{2} \mathrm{~h}\right)$ with research managers and scientists, as well as a profound desk research and an analysis of relevant organisational documents. As we explain below, this triangulation of different methods (Flick 2008) allowed to tackle our research questions from different methodological angles, facilitating a well-rounded analysis.

The interviews were conducted between January 2015 and November 2016 in a high-performing region in AE in NRW (Germany). The strength of the German research system, particularly regarding transfer activities, is often explained by the co-existence and collaboration of universities and other public research institutes (such as the Max Planck Society, the Leibnitz Association or the Helmholtz Society). To grasp this special aspect of $\mathrm{AE}$ in Germany, we included interviewees at one technical university and two other public research institutes in close proximity (one being more applied science and one more basic science oriented) that have close ties to the technical university. Further, we included managers of two nearby technology centres to cover the growing start-up sector in the region. From a total of 21 interviewees, 15 had managerial experience: 9 interviewees held purely managerial positions, most of whom had earlier started an academic career but were now employed as research managers. They worked in different departments responsible for entrepreneurship-related tasks (e.g. patenting, support for start-ups), including a vice-rector, a head of a legal department, several employees of TTOs and leaders of technology centres. Five of the interviewees were scientists in leading positions at a university, public research institution or start-up and were thus also responsible for managerial tasks related to AE. Our interview sample reflects a trend in the German context that managerial tasks are divided between research managers with an academic background (e.g. in law or biosciences) and scientists who, as a result of NPM reforms, were attributed considerably more managerial tasks (Krücken et al. 2013). The 12 interviewed scientists all came from bio- and chemical engineering, a field with high application potential and strong transfer activities (through cooperation with industry or, often in cooperation with the technology centres, in start-up creation). The focus on engineering allowed to cover the broad range of 
commercialization activities within a Triple Helix configuration in the practices of one broader research field. The choice of interviewees also reflects the collaboration of scientists across universities, other public research institutes and start-ups that is relevant for research. We carried out semi-structured "intensive" interviews (Charmaz 2006: 25f) based on the concept of "reflexive peer-to-peer interviews" (Felt et al. 2008). In this interview approach, interviewers are understood as "peers" in the sense that they are active in the academic environment and therefore share experiences with interviewees. This allowed for engaging interviewers and interviewees in a reflexive discussion on the topic, thus gaining more in-depth access to the experiences of scientists within their particular work constellations. We chose this largely individual-centred methodological approach because previous work on commercialization at German universities has shown that linkages to civil society in general seem to "thrive on individual motivation and commitment" (Krücken et al. 2009: 139). This approach was particularly useful for reflecting on how interviewees experience their institutional context, the relevant actors for research commercialization and their own role in AE. All interviews were transcribed and analysed using NVIVO software, following a grounded theory approach (Glaser and Strauss 1998, 2005).

To explore how far the ways in which research managers and scientists attributed different roles in practices of research commercialization also reflected organisational self-representations, we further carried out an analysis of strategic documents and self-representations of the research organisations under study (the technical university, two other public research institutes), such as annual reports, descriptions of transfer services, patent strategies or websites. Further, we analysed self-representations of relevant technology centres or platforms supporting commercialization activities (e.g. webpages, flyers). Following Prior (2003), we approach such documents as a specific text genre, that conveys a certain imagination of a system (in this case of academic entrepreneurship) where documents do not simply describe but define and act upon what they depict. The analysis focused on how the agency of organisations and managerial staff is described, as well as on how the agency of scientists is depicted within the field of AE.

The choice of analysed documents built on a comprehensive desk research to identify relevant documents and map relevant institutions and actors. The desk research also included an analysis of the history of start-up creation in the region, an analysis of founding documents and organigrams of start-ups and research facilities and patenting activity in the respective institutions (via DEPATISnet ${ }^{3}$ ). This provided profound background information for reconstructing activities of key actors. Most importantly, it helped to illuminate the role of two professors (we call them in the following Prof. A and Prof. B) who were frequently mentioned by interviewees as core agents in shaping entrepreneurial culture and the institutional landscape for supporting research commercialization in the region, but repeatedly declined interview requests. Particularly, in cases in which field access proved to be difficult, the approach of triangulating methods allowed gaining a well-rounded analysis of different kinds of agency in $\mathrm{AE}$ in this region.

\section{Results}

In the following, we first describe what kinds of agency are attributed to research managers (as organisational actors) and scientists in our empirical material. Building on 
that, we explore who is ascribed agency of bringing about institutional changes within the Triple Helix configuration.

\section{Agency attributed to research managers \\ Perspective of research managers}

The main narrative thread in interviews with research managers at the technical university was that their role lies in supporting scientists in their attempts to commercialise their research. A research manager at the legal department of the technical university for example saw her role in assisting scientists with the increasing red tape in negotiating contracts with industry, e.g. regarding intellectual property rights:

It was at the beginning of the $90 \mathrm{~s} . .$. and the contractual regulations increased, because collaboration with industry increased.... and we became more engaged in the legal matters. .... With every funding, you have to look, where it comes from, what the conditions are... (RM6).

This support was often described as happening in close consultancy with scientists to free academic entrepreneurship from bureaucratic constraints. In the case of start-up creation this service-function was often also described as minimising risks in the often economically precarious situation of becoming self-employed, as this entrepreneurship trainer put it:

It is important to show the founders how to minimise the risk. That is, I don't need to come to a deadlock, but you need to consider from the beginning - it is called 'effectuation' ... what you are willing to and what you can - invest. And that means time resources, but also financial resources. (RM3).

Most research managers emphasised the good support structure for scientists, e.g. by describing their services as providing "all-in-one-worry-free-package(s)" (RM5) for patenting or saw scientists "overloaded with help" (RM1) when they wanted to create a company. While this university in particular was heavily funded by governmental programmes to foster $\mathrm{AE}$ and boost the knowledge economy in the region, the role of the university in $\mathrm{AE}$ is clearly described as "supporting" (doc5), "accompanying" (doc1, doc3) and "providing" (doc1) services or information, rather than as encouraging or incentivising it.

We find a similar service-oriented attitude in the public research institutes, even though managers here (mostly scientists in managerial positions) acted more from an employer's perspective. Prof. R3 for example, a lab leader and managerial head of the research institute, speaks of scientists more as employees who are paid for inventions and his research institute as rightly "claim[ing] the patent for themselves" and deciding upon its uses. Different to narrations of research managers at the technical university who emphasised their role as supporting self-motivated and self-interested academic entrepreneurs, the research managers at the research institutes tended to also position their institutes as self-interested actors in themselves. 
In many ways though, these institutes also assumed a supporting and facilitating role, e.g. in creating favourable conditions for start-ups to succeed (e.g. by "solidary patent royalties" R3). As we describe in more detail below, this attitude also reflects a deeply rooted respect for the autonomy of scientists and a reluctance to steer their work that was particularly strong at the technical university.

\section{Perspective of scientists}

The way in which scientists described the role of research management largely reflects this attitude, seeing their role mainly in dealing with bureaucratic processes and in helping reduce individual risks in academic entrepreneurship. Particularly when it came to start-up creation, the narrative context for this was often that in this particular region, large companies offering job security and good working conditions competed strongly with the path of becoming a scientific entrepreneur. Particularly more experienced scientists with managerial duties described this combination of "very dry economic prospects in the first years" in a start-up and the fact that "most people can also get other jobs here" (R3) as de-incentivising engagement in AE.

Several examples in our sample across organisations insinuate that research managers indeed find creative ways of mitigating an individual risk in entrepreneurship: scientists who were actively engaged in start-up creation explained how they had negotiated agreements that allowed them to stay with one foot at a university or research institute to start their company from an economically safe position. For example, a quite senior researcher kept his permanent job at one of the public research institutes and just reduced workload in his contract to work on the start-up:

And the institute supports that (...) I got a contractual change for three years and I have the possibility to decide 3 months to the end of the year if I would like to change it back. That means, it's not like - even though I know the financial situation of the company very well $-(.$.$) . My risk is not very high, that is very comforting. (R7).$

The research management was seen as accommodating flexible contractual agreements in the research organisation.

Scientists described cross-sectoral hiring practices that made it possible to return to university in case a start-up fails as a further way in which research organisations reduced career risk and supported AE: some scientists had changed quite frequently between employment at universities and start-ups, especially when they had reasons to expect that the start-up would not be a sustainable success. Such a flexible hiring practice in one case made it possible for a network of scientists to try to commercialise the same analytical technology over the past 15 years, even though the first two start-ups they founded never took off in terms of economic success. Some of the core scientists thus had decided to opt for more secure researcher career option again, but were later encouraged by new funding opportunities and the willingness of both, a research institute and the technical university to negotiate economically favourable employment conditions for scientists to create another start-up. In this context, the agency of research managers can be observed in supporting high-risk AE by adapting employment and cross-sectoral hiring practices allowing for non-linear researcher careers. 


\section{Agency attributed to scientists \\ Perspective of research managers}

The mirror image of how research managers saw their own role as facilitators was that they depicted scientists largely as autonomous and self-motivated, and as taking the initiative in AE. This is for example reflected in how this manager of a technology centre talks about scientists who seek her support:

They will come to us for a first meeting and it is my task then to guide them and to look and see how we can support the formation of this company and what can we offer the founders? (RM1).

Such statements conveyed a strong sense of respect for the autonomy and initiative of scientific entrepreneurs. Even if scientists side-lined or subverted legal regulations, e.g. in "only starting to disclose their invention after the foundation of their company" (RM1) to avoid intellectual property claims of the university, this was not framed as problematic but rather as legitimate practice, as it allowed scientists to act without organisational constraints (RM2). A broad degree of autonomy was also guaranteed by involving scientists in negotiations with industry. The assumption for example was that scientists knew best whether there are potential customers for inventions or not (RM6).

This attitude was also reflected in strategic documents of the technical university that often emphasise supposed benefits of commercialization activities (e.g. patenting) for scientists' excellence and reputation or in terms of creating new opportunities for acquiring funds (from industry) and creating freedom to conduct research in less budget-constrained conditions (doc6). This, too, appeals to the motive of freedom of research.

\section{Perspective of scientists}

Despite above descriptions of "all-in-one-worry-free-package(s)" that the technical university or research institute provided together with the technology centres, scientists described their experiences being scientific entrepreneurs as having to tediously manage to craft tailored solutions for their specific case, often oppose institutional rules and performance norms. Even though many examples show that institutions allowed for creative contractual and career solutions, particularly start-up creation was perceived as difficult to arrange alongside a scientific career. A senior researcher and head of a public research institute, for example, critically discussed leaving academia to create a start-up as high-risk undertaking:

This blurring is not impossible, but you should not have illusions here, how difficult

that is. Because getting a position in a research institute is very competitive. ... when you ... spend your time working on a company, then you lack the time, and the publications, and the findings, that you would otherwise have spent doing basic research. And this is why you will be less successful in the competition for a professorship. (R1).

This critical perspective though contrasted with other stories about younger scientists who had simultaneously or consecutively worked on a start-up and in academia. R1 himself had in his young age created a company before going back to a research 
institute and later became the head of the institution. Interviewees frequently mentioned different similar examples, e.g. of a researcher who created two start-ups after leaving a research institute and now got a professorship at a nearby university or yet another who had been involved in a start-up for approximately 10 years and had only recently got a professorship in academia again. According to such narrations, non-linear, cross-sector careers seemed to be relatively common in the region across universities, research institutes and start-ups.

Overall, many scientists attributed to themselves a form of agency that can be described as bricolage, in which different practices are bundled for negotiations and result in creative, flexible solutions of dealing with sometimes static structural conditions at their research organisation (e.g. career patterns, employment regulations). Even when they were aware of support structures at their organisations, collaborations with industry were often experienced as difficult to pursue in practice due to institutional barriers. At one institute, two scientists described a "schizophrenic situation" (R1, see also R2) on the one hand being incentivised with support structures, but being discouraged by bureaucratic requirements, amongst others because collaboration with industry is easily interpreted as cross-funding of industrial applications with public money.

The example of a joint start-up by a professor of a university (Prof. B) and a researcher at a research institute (R7) may exemplify how scientists described their respective situations as quite unique, not conforming institutional norms and the practice of academic entrepreneurship as requiring creative solutions:

We had discussions with ... [the technology centre] and also thought about [moving into lab spaces there], because it is a bit difficult with our official addresses. Our registered office is still... the private apartment of Prof. B. for pragmatic reasons, but we now try to get our correspondence via [the university].... I discussed this with [university administration] ... and she said that we are the only ones... - so it seems that [our solution across university and institute] is formally not existing... but obviously, it is possible. ... in the first year, we asked about contractual agreements and everyone was confused... (R7).

Particularly for start-up creation though, the role that scientists ascribed to themselves was that of being able to negotiate creative ways of forging an entrepreneurial career. They often also described themselves as risk-takers who often changed between jobs in universities, institutes and start-ups to be able to realise a venture (R6).

This bricolage-like agency is also described for collaborations with industry. The earlier mentioned professor R8 for example explains how, for being able to continue his collaborations with industry, he created an environment to continuously pursue his industry collaborations by adapting to new labour regulations, shifting flexibly to changing funding opportunities (e.g. transdisciplinary EU funding), and legal changes (e.g. regarding patenting).

\section{Institutional entrepreneurship in academic entrepreneurship}

Beyond this bricolage-like agency, we also find narrations of scientists who pursued a career strategy that led them into leading positions (with managerial responsibilities) who actively and sustainably change their institutional environments to suit their commercialization activities. 
Research managers typically saw those leading scientists as key to the entrepreneurial orientation of their organisation. Related to this was the view that an entrepreneurial attitude is something that is somehow naturally anchored in the personality of these selected scientists (RM1). Following this logic, research managers saw their role in following the initiative of such outstanding scientific entrepreneurs in establishing new institutional regulations. A research manager at a technology centre explained the establishment of an entrepreneurship centre as a success due to the initiative of the head of a public research institute (Prof. A). Despite two negative expert assessments about the feasibility of creating such a centre, it became a reality due to the lobbying activities of Prof. A

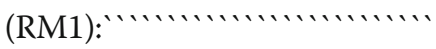

An up-to-date example is [this Prof.] who had this idea, that we could ... create a centre ... it is his idea, and we then try to get the respective partners on board. ... So, it is one of our tasks to do project leadership and organisation. (RM1).

A research manager at the technology transfer office (TTO) of the technical university describes Prof. A similarly, as active in local political networks:

There is this plan of the city. It was completely unthinkable ten years ago. And that's something that was pushed by [this] Prof. (...) And I think we can expect that a lot of additional things will be happening in [this research field]. (RM2).

The strong leadership role of Prof. A is not only accepted by research managers across organisations, but also highly valued. Through desk research and document analysis, we could see that he indeed held key functions in several start-ups that acted as intermediary structures between scientists and industry. The level of trust and belief in such scientists also translated into the level of support they enjoyed by research managers that the latter TTO manager nicely boiled down to the credo "Give those professors more money!" (RM2).

Another example for how scientists in managerial positions achieved durable institutional change was Prof. R8. After starting out as one of the first professors in the region who actively pursued collaborations with industry, he later applied for being a member of the leadership team of the technical university and used this influence to create a better environment for commercialization. Amongst others, he was eager to stress his agency in establishing a new internal regulation for dividing patent royalties:

I have established a system in which ... the professorship can decide whether they pay for patenting themselves and also gets $100 \%$ of returns. (R8).

This new regulation gave professors the opportunity to choose greater degrees of entrepreneurial freedom and decision-making in handling their inventions and allowed revenues from patents to be directly invested in research at the respective chairs. In this way, he had significant influence on the procedures and rules for research commercialization at this university.

Beyond creating infrastructures for facilitating academic entrepreneurship at their institutions though, both, Prof. A and Prof. R8, were also key actors in establishing new research infrastructures for collaborating with industry on a continuous basis to produce knowledge with application potential. This included setting up new doctoral programmes, new 
research and teaching positions and new research buildings that were jointly funded by state or federal governments and larger companies in the region. Prof. R8 explained this as win-win situation for both the technical university and the industry partner:

I claim that it is important for both sides. One example: A few years ago, my faculty - and I was involved in that - has established a [joint research institute] ... It is a facility in which topics are research that are of mutual interest. But of course, $\mathrm{PhD}$ students can work there and will get a PhD degree from us. (R8).

In the interview, he explains how the joint university-industry institute had now institutionalised the already strong relationship between his $\mathrm{PhD}$ training and the research interests of the involved company. At least six PhD students had switched from working at university to this company within 2 years, a relationship that is now made durable within the joint institute. These examples show how some scientists in leading positions play a key role in shaping the Triple Helix configuration in this particular region by mobilising resources and support for durable institutional change.

\section{Discussion and conclusions}

Answering the calls from previous studies to explore how the individual level and the organisational level intertwine in academic entrepreneurship (Huyghe and Knockaert 2015: 155) and to understand the agency of individuals in the Triple Helix relationships (Ranga and Etzkowitz 2013), we have explored how both research managers and scientists narrate and ascribe agency in research commercialization in their particular contexts. Although new regulations such as the abolishment of the professors' privilege have tied AE closer to the university, our study confirms, that this tie is a rather "loose coupling between the formal structure and the activity structure" (Lange and Krücken 2011: 365). Unlike the expectation that research managers would see their role in demanding more engagement in the third mission from scientists in their organisations as suggested by literature on strong managerial control of universities in the USA as well as other Anglo-Saxon higher education systems (Geiger and Sá 2008; Bleiklie et al. 2015; Rhoades 1998), research managers in our German example framed themselves as passive service-providers for scientists' self-motivated commercialization activities. At the same time, they were ascribed agency by scientists in terms of facilitating creative employment arrangements so as to mitigate the risk of not having job security via the start-up and allowing smooth transitions for the scientists' career between two sectors. Interestingly, we observe that this self-perception of research managers being service providers was more dominant in the university setting than in the research institutes. The power of academic self-governance and professors in German universities has traditionally been high and due to a strong role of path-dependencies to a large extent still exists (Hüther and Krücken 2018).

In terms of the agency of scientists, research managers perceive them as self-motivated driven individuals who exhibit a strong entrepreneurial character and are highly creative risk-takers. Many of studied scientists saw it natural to negotiate the institutional arrangements and find flexible solutions to deal with the structural bureaucratic barriers within their research organisations even though sometimes it was really difficult to deal with the highly established bureaucracies. Scientists also engage 
in risky developmental work, but they tend to avoid taking a combination of personal and professional career risks. Rather, they try to stay with one foot in the "safe" position at research organisations to avoid existential risk. We observe them as bricoleurs using the resources they have to negotiate with research managers temporary organisational arrangements to flexibly accommodate their ventures as well as some of them as institutional entrepreneurs who use their prestige (these are usually professors), entrepreneurial skills as well as political networks to acquire governmental as well as industrial funding to create new institutions, overcome or create new rules and establish new structures to facilitate AE. Following Etzkowitz's typology of entrepreneurial scientists, they are "craftspersons" who like to participate in the whole innovation process, and who make innovation processes possible by gathering necessary resources and sometimes act as "sustainers" by rather modest and pragmatic institution-building (Etzkowitz 1997: 146).

Overall, trust in scientific entrepreneurs from research managers, scientific standing and leadership of scientific entrepreneurs, as well as type of AE-e.g. start-up creation or collaboration with industry-were very important for the engagement in shaping the Triple Helix relationships in the region. Given the regulatory constraints and path-dependencies of research organisations, the agency of scientific entrepreneurs, especially their ability to manoeuvre, negotiate and find creative solutions regarding their funding and career paths points to their central role in navigating and shaping the organisational dynamics towards AE in their research organisations. Particularly, studied scientists with managerial functions are observed as leaders of institutional change in creating new hybrid infrastructures (created through co-funding of industry, government and research organisation) for producing knowledge, and for steering it towards $R \& D$ areas that are relevant for industry. These scientists with managerial function often bear resemblance with the "mogul" type in Etzkowitz's typology, as they see themselves and are described by others as strong leaders in shaping not only their own ventures and firms, but creating new institutional infrastructures for research commercialization (Etzkowitz 1997: 146).

Still, it is important to underscore that the studied scientific entrepreneurs operate in an environment that is highly conducive for scientific entrepreneurship-with numerous governmental financial opportunities, strong regional science infrastructure, as well as in the research organisations (technical university and the research institutes) that do create rooms for manoeuvre for scientists. Especially, the technical university is actively supporting their scientists through new contractual arrangements, cross-sectoral hiring practices, provision of support structures for research commercialization, or following the lead of scientific entrepreneurs in creatively interpreting legal regulations.

These findings suggest that "bricolage" activities and the trust of research managers in the leadership and autonomy of scientific entrepreneurs have prepared the ground for durable institutional change (e.g. in the case of R8 and Prof. A) which also can be the ground for institutional entrepreneurship to take place and reshape the Triple Helix relationships in the particular context. The extent to which these two different types of agency are co-existing and are distinct merits more attention in the future studies on AE.

This study has shown the complexity of the context-specific relationships between individual and organisational levels in $\mathrm{AE}$ and pointed out the important role of 
embedded individual agency in shaping institutional opportunity structures for $\mathrm{AE}$ within the Triple Helix context. This is in line with previous studies that point to the individual and group agency in the university or Triple Helix contexts (e.g. Hasanefendic et al. 2017; Chatterjee et al. 2018, Schmidt and Lauer 2016). Specifically, research managers in our study who had a scientific position and managerial function at the same time were very much in line with what Ranga and Etzkowitz (2013) define as "innovation organisers", while the other scientists fulfilled the roles of entrepreneurial scientists who combine their research interests with innovation and entrepreneurial behaviour. Our study shows in more detail the types of agency that these two actors have in shaping the institutions. At the same time, our findings point to the limits of agency exercised by the research managers, as they mainly adopt a service role instead of proactively shaping institutions. Even though this gives leeway for entrepreneurial scientists to act, stronger presence of innovation organisers amongst researcher managers who engage pro-actively in creating accommodating structures for boundary crossing in the Triple Helix context would be beneficial.

Studies on how different scientific entrepreneurs and research managers navigate their environments in other sectors, such as creative industries or in low-resourced Triple Helix contexts, could show an even broader variety of ways in which they act as change agents (or refrain from doing so). We would expect context-specific differences, as in different regional and national governance regimes due to various historical, cultural and institutional path dependencies (Sigl and Leišyte 2018). Further studies thus should expand the contextual reach by addressing and comparing different types of research organisations and regional specifics. Such studies would be much needed to broaden our understanding about the particular organisational conditions and academic cultures that foster and shape the individual agency in the Triple Helix context.

Our study has important implications for research managers. When scientists' autonomy is respected by the organisation and when research managers provide rooms for manoeuvre, scientific entrepreneurs cross the boundaries and create more balanced Triple Helix context shifting flexibly between traditional academic values and the capitalization of knowledge (Etzkowitz 1997). They do so either by altering the institutional framework within the existent organisation (engage in institutional entrepreneurship), or by finding flexible temporary contractual arrangements to move between research organisation and the private sector engaging in AE (through bricolage). Research managers would benefit by creating room for manoeuvre and openness to dialogue with scientists in facilitating this flexibility in employment contracts and careers. Entrepreneurial culture, financial incentives and manifold other tools to promote academic entrepreneurship may be effective to raise awareness or interest of scientists in knowledge transfer. But it is really about spotting and fostering institutional entrepreneurs to take centre stage and create opportunity structures and processes which facilitate concrete initiatives of knowledge and technology transfer in research organisations that may alter the Triple Helix arrangements in a particular setting.

Organisations could learn from this study that governance arrangements that promote security in career progression do not necessarily impede the $\mathrm{AE}$ initiatives but that organisational flexibility and the opportunity to keep an academic position as a back-up strategy may soften the involved risks and in fact support institutional entrepreneurs in mitigating risks. Our study thus supports the hypothesis that career 
structures and employment security are important factors for strengthening research collaborations (cp. Cattaneo et al. 2018). Thus, the human resources strategies and practices alongside the technology transfer practices should not be left as a blind spot in research organisations when thinking about enhancing $\mathrm{AE}$ engagement.

\section{Endnotes}

${ }^{1}$ Academic entrepreneurship is here defined as activities that contribute to the commercialization of knowledge produced at academic institutions (e.g. collaboration with industry, start-up creation and patenting).

${ }^{2}$ We understand research organisations as a broad term to denote universities, universities of applied sciences and public research institutes.

${ }^{3}$ https://www.dpma.de/english/index.html

\section{Additional file}

Additional file 1: Translation of the abstract into Arabic. (PDF $42 \mathrm{~kb}$ )

\section{Abbreviations}

AE: Academic entrepreneurship; IPR: Intellectual property rights; NPM: New Public Management; NRW: North RhineWestphalia; TTO: Technology transfer office

\section{Acknowledgements}

We acknowledge our interviewees for their time and availability. We thank the reviewers and editors for their comments.

\section{Funding}

The authors declare that they have no competing interests.

\section{Availability of data and materials}

The interview data generated and analysed during the current study are not publicly available due confidentiality reasons.

\section{Authors' contributions}

LL designed the study, discussed the implementation of the study and wrote parts of the manuscript. LS carried out the interviews and analysed them and wrote parts of the manuscript. Both authors read and approved the final manuscript.

\section{Competing interests}

The authors declare that they have no competing interests.

\section{Publisher's Note}

Springer Nature remains neutral with regard to jurisdictional claims in published maps and institutional affiliations.

\section{Author details}

${ }^{1}$ Center for Higher Education, Faculty of Business and Economics, TU Dortmund University, Vogelpothsweg 78, TU Dortmund, 44227 Dortmund, Germany. ${ }^{2}$ Research Platform for Responsible Research and Innovation, University of Vienna, Universitätsstrasse 7/6th floor, 1010 Vienna, Austria.

Received: 13 July 2018 Accepted: 5 November 2018

Published online: 18 December 2018

\section{References}

Abreu M, Grinevich V (2013) The nature of academic entrepreneurship in the UK: widening the focus on entrepreneurial activities. Res Policy 42(2):408-422

Balven R et al (2018) Academic entrepreneurship: the roles of identity, motivation, championing, education, work-life balance and organizational justice. Acad Manag Perspect 32(1):21-42

Battilana J, Leca B, Boxenbaum E (2009) How actors change institutions: towards a theory of institutional entrepreneurship. Acad Manag Ann 3(1):65-107. https://doi.org/10.1080/19416520903053598

Berman EP (2012) Creating the market university: how academic science became an economic engine. Princeton University Press, Princeton. https://doi.org/10.1093/jahist/jas566

Bleiklie I, Enders J, Lepori B (2015) Organizations as penetrated hierarchies: environmental pressures and control in professional organizations. Organ Stud 36(7):873-896. https:/doi.org/10.1177/0170840615571960 
BMBF - Bundesministerium für Bildung und Forschung (2002) Spinoff-Gründungen aus der Öffentlichen Forschung in Deutschland. Exist-Studien 4. BMBF, Bonn

BMBF - Bundesministerium für Bildung und Forschung (2014) Bundesbericht Forschung und Innovation 2014. BMBF, Bonn BMWE - Bundesministerium für Wirtschaft und Energie (2015) Wettbewerb "EXIST-Gründungskultur - Die Gründerhochschule". https://www.exist.de/DE/Programm/Exist-Gruendungskultur/EXIST-Gruenderhochschule/inhalt.html. Accessed 12 Dec 2015.

Bozeman B, Fay D, Slade CP (2013) Research collaboration in universities and academic entrepreneurship: the state of the art. J Technol Transfer 38:1-67. https://doi.org/10.1007/s10961-012-9281-8

Cattaneo M, Horta H, Meoli M (2018) Dual appointments and research collaborations outside academia: evidence from the European academic population, studies in higher education, Published online 09 July. https://doi.org/10.1080/03075079. 2018.1492534

Charmaz K (2006) Constructing grounded theory. A practical guide through qualitative analysis. Sage, London

Chatterjee D, Leisyte L, Dasappa S, Sankaran B (2018) University research commercialization in emerging economies: a glimpse into the 'black box'. Sci Public Policy 45(3):361-372. https://doi.org/10.1093/scipol/scx066 [published online 18 Oct 2017]

D'Este P, Patel P (2007) University-industry linkages in the UK: what are the factors underlying the variety of interactions with industry? Res Policy 36(9):1295-1313. https://doi.org/10.1016/j.respol.2007.05.002

Davey T, Rossano S, van der Sijde P (2015) Does context matter in academic entrepreneurship? The role of barriers and drivers in the regional and national context. J Technol Transfer 41(6):1457-1482. https://doi.org/10.1007/s10961-015-9450-7

De Boer HF, Enders J, Schimank U (2007) Comparing higher education governance systems in four European countries. In: Soguel NC, Jaccard P (eds) Governance and performance of education systems. Springer, Dordrecht, pp 35-54

De Silva L (2012) Academic entrepreneurship in a resource constrained environment. University of Manchester, Dissertation

DiMaggio PJ (1988) Interest and agency in institutional theory. In: Zucker L (ed) Institutional patterns and organizations. Ballinger, Cambridge, pp 3-21

Djokovic D, Souitaris V (2008) Spinouts from academic institutions: a literature review with suggestions for further research. J Technol Transfer 33(3):225-247. https://doi.org/10.1007/s10961-006-9000-4

Doganova L (2013) Transfer and exploration: two models of science-industry intermediation. Sci Public Policy 40(4):442-452. https://doi.org/10.1093/scipol/sct033

Doppelberger T (2012) Fraunhofer Venture. In: Presented at the European TTO circle, Munich Available at: https://ec.europa. eu/jrc/en/network/european-tto-circle/meeting-4

EC - European Commission (2015) Innovation union scoreboard 2015. Publications Office of the European Union, Luxembourg

EC - European Commission (2018) Regional innovation monitor plus. Available at https://ec.europa.eu/growth/toolsdatabases/regional-innovation-monitor/base-profile/north-rhine-westphalia, Accessed 24 June 2018.

Etzkowitz H (1997) The entrepreneurial university and the emergence of democratic corporatism. In: Etzkowitz H, Leydesdorff L (eds) Universities and the global knowledge economy, pp 141-154

Etzkowitz H (2008) The triple helix: university-industry-government/innovation in action. Routledge, New York

Etzkowitz H (2013) Anatomy of the entrepreneurial university. Soc Sci Inf 52(3):486-511. https://oi.org/10.1177/0539018413485832

Etzkowitz H, Leydesdorff $L$ (2000) The dynamics of innovation: from National Systems and "mode 2" to a triple Helix of university-industry-government relations. Res Policy 29(2):109-123. https://doi.org/10.1016/S0048-7333(99)00055-4

Felt U, Fochler M, Müller R (2008) Biography and/or career? Knowing and living in contemporary research. In: Paper read at the politics of knowing. Research, Institutions and Gender in the Making, Prague

Felt U, Glanz M (2004) University autonomy in Europe: shifting paradigms in university research. Managing university autonomy: shifting paradigms in university research. In: Proceedings of the Seminar of the Magna Charta Observatory, 15 September 2003. Boninia University Press, Bologna

Flick U (2008) Managing quality in qualitative research. Sage Publications

Fochler M (2016) Beyond and between academia and business: how Austrian biotechnology researchers describe high-tech startup companies as spaces of knowledge production. Soc Stud Sci 46:259-281. https:/doi.org/10.1177/0306312716629831; http://sss.sagepub.com/content/46/2/259.abstract

Frølund L, Ziethen M (2016) The wisdom of the intermediary: the role, function, and ways-of-being of the intermediary in a strategic program for university-industry relations. Triple Helix 3(1):9. https://doi.org/10.1186/s40604-016-0039-4

Garud R, Hardy C, Maguire S (2007) Institutional entrepreneurship as embedded agency: an introduction to the special issue. Organ Stud 28(7):957-969. https://doi.org/10.1177/0170840607078958

Geiger RL, Sá CM (2008) Tapping the riches of science: universities and the promise of economic growth. Harvard University Press

Glaser BG, Strauss AL (1998) (2005) Grounded theory: Strategien qualitativer forschung (Original title: the discovery of grounded theory), 2nd edn. Huber, Bern

Goel R, Göktepe-Hulten D (2017) What drives academic patentees to bypass TTOs? Evidence from a large public research organization. J Technol Transf 43(1):240-258. https://doi.org/10.1007/s10961-017-9595-7

Grimaldi R, Kenney M, Siegel DS, Wright M (2011) 30 years after Bayh-dole: reassessing academic entrepreneurship. Res Policy 40:1045-1057

Hagedoorn J, Link AN, Vonortas NS (2000) Research partnership. Res Policy 29(4-5):567-586. https://doi.org/10.1016/50048-7333(99)00090-6

Hasanefendic S, Birkholz JM, Horta H, van der Sijde P (2017) Individuals in action: bringing about innovation in higher education. Eur J High Educ 7(2):101-119

Hottenrott H, Lawson C (2017) A first look at multiple institutional affiliations: a study of authors in Germany, Japan and the UK. Scientometrics 111(1):285-295

Hüther O, Krücken G (2018) Higher education in Germany. Recent developments in an international perspective, vol 49. Springer

Huyghe A, Knockaert M (2015) The influence of organizational culture and climate on entrepreneurial intentions among research scientists. J Technol Transfer 40(1):138-160. https://doi.org/10.1007/s10961-014-9333-3

Huyghe A, Knockaert M, Piva E, Wright M (2016) Are researchers deliberately bypassing the technology transfer office? An analysis of TTO awareness. Small Bus Econ 47(3):589-607

Kezar A (2014) How colleges change. Understanding, leading, and enacting change. Routledge, New York

Kleinman DL, Osley-Thomas R (2014) Uneven commercialization: contradiction and conflict in the identity and practices of American universities. Minerva 52(1):1-26. https://doi.org/10.1007/s11024-014-9248-z 
Klofsten M, Jones-Evans D (2000) Comparing academic entrepreneurship in Europe: the case of Sweden and Ireland. Small Bus Econ 14(4):299-309. https://doi.org/10.1023/A:1008184601282

Krücken G (2003) Learning the 'new, new Thing': on the role of path dependency in university structures. High Educ 46(3): 315-339. https://doi.org/10.1023/A:1025344413682

Krücken G, Blümel A, Kloke K (2013) The managerial turn in higher education? On the interplay of organizational and occupational change in German academia. Minerva 51(4):417-442. https://doi.org/10.1007/s11024-013-9240-z

Krücken G, Meier F, Müller A (2007) Information, cooperation, and the blurring of boundaries - technology transfer in German and American discourses. High Educ 53(6):675-696. https://doi.org/10.1007/s10734-004-7650-4

Krücken G, Meier F, Müller A (2009) Linkages to the civil society as 'leisure time activities'? Experiences at a German university. Sci Public Policy 36(2):139-144. https://doi.org/10.3152/030234209X406854

Kulicke M (2014) 15 years of EXIST University-based start-up programmes. Working paper. Fraunhofer Institute for Systems and Innovation Research, Karlsruhe

Kulicke M, Dornbusch F, Berghäuser H, Seus S (2014) Erfolgskontrolle des Programms SIGNO - "Schutz von Ideen für die Gewerbliche Nutzung" des Bundesministeriums für Wirtschaft und Energie. Fraunhofer Institute for Systems and Innovation Research, Karlsruhe

Lam A (2011) What motivates academic scientists to engage in research commercialization: 'gold', 'ribbon' or 'puzzle'? Res Policy 40:1354-1368. https://doi.org/10.1016/.j.respol.2011.09.002

Lange S, Krücken G (2011) German universities in the new knowledge economy. Current changes in research conditions and university-industry relations. In: Rhoten D, Calhoun C (eds) Knowledge matters. The public mission of the research university. Columbia Press, New York, pp 342-376

Latour B (1996) Aramis, or the love of technology. Harvard University Press, Cambridge

Leišyte L (2007) University governance and academic research: case studies of research units in Dutch and English universities. University of Twente, Dissertation

Leišyte $L$ (2011) University commercialization policies and their implementation in the Netherlands and the United States. Sci Public Policy 38(6):437-448. https://doi.org/10.3152/030234211X12960315267

Leišyte $L$ (2015) Changing academic identities in the context of a Managerial University - bridging the duality between professions and organizations. Evidence from the U.S. and Europe. In: Cummings WK, Teichler U (eds) The relevance of academic work in comparative perspective, the changing academy - the changing academic profession in international comparative perspective, vol 13, pp 59-73

Leišytè L, Dee J (2012) Understanding academic work in a changing institutional environment. Faculty autonomy, productivity and identity in Europe and the United States. In: Smart JC, Paulsen M (eds) Higher education: handbook of theory and research, vol 27. Springer, Dordrecht, pp 123-206

Leišyte L, Enders J, de Boer H (2010) Mediating problem choice: academic researchers' responses to changes in their institutional environment. In: Whitley R, Engwall L, Gläser J (eds) Reconfiguring knowledge production: changing authority relationships in the sciences and their consequences for intellectual innovation. Oxford University Press, Oxford, pp 266-299

Leišyte L, Hosch-Dayican B (2016) Boundary crossing and maintenance among UK and Duch bioscientists: Towards hybrid identities of academic entrepreneurs. In: Leišyte L, Wilkesmann U (eds) Organizing academic work in higher education: Teaching, learning and identities. Routledge, Abingdon, pp 223-242

Leisyte L, Vilkas M, Staniskiene E, Zostautiene D (2017) Balancing countervailing processes at a Lithuanian university. Learn Organ 24(5):327-339

Link AN, Siegel DS (2007) Innovation, entrepreneurship, and technological change. Oxford University Press, Oxford

Lockett A, Wright M, Franklin S (2003) Technology transfer and universities' spin-out strategies. Small Bus Econ 20(2):185-200. https://doi.org/10.1023/A:1022220216972

Louvel S (2013) Understanding change in higher education as bricolage: how academics engage in curriculum change. J High Educ 66:669-691. https://doi.org/10.1007/s10734-013-9628-6

Maguire S, Hardy C, Lawrence TB (2004) Institutional entrepreneurship in emerging fields: HIV/AIDS treatment advocacy in Canada. Acad Manag J 47(5):657-679. https://doi.org/10.2307/20159610

Mahr U (2012) Max Planck Innovation GmbH-Start-Up Management for Max-Planck- Society. In: Presented at European TTO Circle, Munich Available at: https://ec.europa.eu/jrc/en/network/european-tto-circle/meeting-4

Markman GD, Siegel DS, Wright M (2008) Research and technology commercialization. J Manag Stud 45(8):1401-1423. https://doi.org/10.1111/j.1467-6486.2008.00803.x

Meyer M, Kearnes M (2013) Introduction to special section: intermediaries between science, policy and the market. Sci Public Policy 40(4):423-429

Meyers AD, Pruthi S (2011) Academic entrepreneurship, entrepreneurial universities and biotechnology. J Commer Biotechnol 17(4):349-357. https://doi.org/10.1057/jcb.2011.22

Olmos-Peñuela J, Benneworth P, Castro-Martínez E (2015) What stimulates researchers to make their research usable? Towards an 'openness' approach. Minerva 53(4):381-410. https://doi.org/10.1007/s11024-015-9283-4

Perkmann M, Tartari V, McKelvey M, Autio E, Boström A, D'este P et al (2013) Academic engagement and commercialization: a review of the literature on university-industry relation. Res Policy 42(2):423-442. https://doi.org/10.1016/j.respol.2012.09.007

Powell WW, DiMaggio PJ (1991) The new institutionalism in organizational analysis. University of Chicago Press

Prior L (2003) Using documents in social research. Sage Publications, London

Ranga M, Etzkowitz H (2013) Triple Helix systems: an analytical framework for innovation policy and practice in the knowledge society. Ind High Educ 27(4):237-262

Rhoades G (1998) Managed professionals: unionized faculty and restructuring academic labor. State University of New York Press

Rizzo U (2015) Why do scientists create academic spin-offs? The influence of the context. J Technol Transfer 40(2):198-226. https://doi.org/10.1007/s10961-014-9334-2

Rosa P, Dawson A (2006) Gender and the commercialization of university science: academic founders of spinout companies. Entrep Reg Dev 18(4):341-366. https://doi.org/10.1080/08985620600680059

Schmidt CJ, Lauer S (2016) Institutional (teaching) entrepreneurs wanted! - considerations on the professoriate's potency to enhance academic teaching in Germany. In: Leišyte L, Wilkesmann U (eds) Organizing academic work: teaching, learning, and identities. Routledge, London, pp 159-190 
Schmitz A et al (2017) Innovation and entrepreneurship in the academic setting: a systematic literature review. Int Entrep Manag J 13(2):369-395

Shapin S (2008) The scientific Lifes. A moral history of a late modern vocation. University of Chicago Press

Siegel DJ (2008) Building a pipeline for diversity through intersectoral collaboration. High Educ 55(5):519-535

Siegel DS, Waldman DA, Atwater LE, Link AN (2004) Toward a model of the effective transfer of scientific knowledge from academicians to practitioners: qualitative evidence from the commercialization of university technologies. J Eng Technol Manag 21(1-2):115-142. https://doi.org/10.1016/j.jengtecman.2003.12.006

Siegel DS, Wright M (2015) Academic entrepreneurship: time for a rethink? Br J Manag 26:582-595. https://doi.org/10.1111/ 1467-8551.12116

Sigl L, Leišyte L (2018) Imaginaries of invention management: comparing path dependencies in east and West Germany. Minerva 56(3):357-380. https://doi.org/10.1007/s11024-018-9347-3

Thursby JG, Thursby MC (2005) Gender patterns of research and licensing activity of science and engineering faculty. J Technol Transf 30(4):343-353. https://doi.org/10.1007/s10961-005-2580-6

Tijssen RJW (2006) Universities and industrially relevant science: Towards measurement models and indicators of entrepreneurial orientation. Res Policy 35(10):1569-1585

Tuunainen J, Knuuttila T (2009) Intermingling academic and business activities. Sci Technol Hum Values 34:684-704. https://doi.org/10.1177/0162243909337118; http://sth.sagepub.com/cgi/content/abstract/34/6/684

Volkmann C, Grünhagen M (2014) Integrated support for university entrepreneurship from entrepreneurial intent towards behaviour: the case of the German 'EXIST' policy programme. In: Fayolle A, Redford DT (eds) Handbook on the entrepreneurial university. Edward Elgar, Cheltenham

von Proff S, Buenstorf G, Hummel M (2012) University patenting in Germany before and after 2002: what role did the Professors' privilege play? Ind Innov 19(1):23-44. https://doi.org/10.1080/13662716.2012.649060

Wentland A, Knie A, Ruhrort L, Simon D, Egeln J, Aschhoff B, Grimpe C (2012) Forschen in getrennten Welten: konkurrierende Orientierungen zwischen Wissenschaft und Wirtschaft in der Biotechnologie, 1st edn. Nomos, Baden-Baden

Werker C, Ubacht J, Ligtvoet A (2017) Networks of entrepreneurs driving the triple Helix: two cases of the Dutch energy system. Triple Helix 4(4):1-25. https://doi.org/10.1186/s40604-017-0047-z

Whitley R, Engwall L, Gläser J (2010) Reconfiguring knowledge production: changing authority relationships in the sciences and their consequences for intellectual innovation. Oxford University Press

Wright M, Clarysse B, Lockett A, Knockaert M (2008) Mid-range universities' in Europe linkages with industry: knowledge types and the role of intermediaries. Res Policy 37(8):1205-1223. https://doi.org/10.1016/j.respol.2008.04.021

Ylijoki OH (2003) Entangled in academic capitalism? A case-study on changing ideals and practices of university research. High Educ 45:307-335

\section{Submit your manuscript to a SpringerOpen ${ }^{\circ}$ journal and benefit from:}

- Convenient online submission

Rigorous peer review

- Open access: articles freely available online

- High visibility within the field

- Retaining the copyright to your article

Submit your next manuscript at $\boldsymbol{s p r i n g e r o p e n . c o m ~}$ 